\title{
Cultural and economic negotiation: a new perspective on the Neolithic Transition of Southern Scandinavia
}

Kurt J. Gron ${ }^{1, *} \&$ Lasse Sørensen ${ }^{2}$

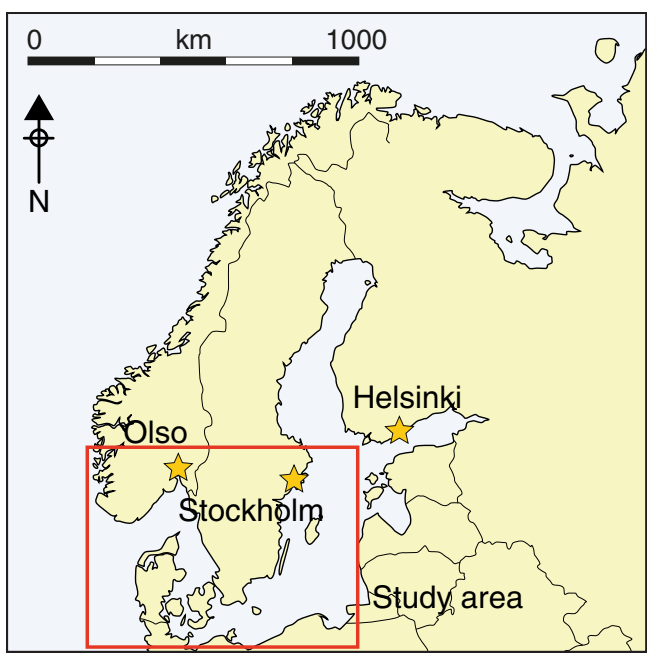

The diversity of archaeological evidence for the adoption of farming in Northern Europe has led to competing hypotheses about this critical shift in subsistence strategy. Through a review of the archaeological material alongside ethnographic evidence, we reconsider the Neolithic Transition in Southern Scandinavia, and argue for both continuity and change during the early Funnel Beaker Culture (c. 4000-3500 cal BC). A new model is proposed for understanding the processes of regional transition-one which allows for compromise between the dominant explanatory frameworks. We conclude that the first centuries of the Scandinavian Neolithic saw cultural and economic negotiation between the last foragers and the first farmers. This has major implications for the understanding of agricultural origins in Northern Europe.

Keywords: Scandinavia, Neolithic Transition, Ertebølle Culture, Funnel Beaker Culture

\section{Introduction}

After expanding from Central Europe, Linearbandkeramik (LBK) farmers halted in the Northern European Plain. From c. 5500-4000 BC, foragers inhabited the north of Europe, and farmers the south (Klassen 2004). The earliest period of the subsequent Southern Scandinavian Neolithic (Early Neolithic I, 4000-3500 BC) is poorly understood. The Early Neolithic I is the first period of the Funnel Beaker Culture (hereafter TRB) and

1 Durham University, Department of Archaeology, South Road, Durham DH1 3LE, UK

2 The National Museum of Denmark, Frederiksholms Kanal 12, 1220 Copenhagen K, Denmark

Author for correspondence (Email: k.j.gron@durham.ac.uk)

(C) Antiquity Publications Ltd, 2018. This is an Open Access article, distributed under the terms of the Creative Commons Attribution licence (http://creativecommons.org/licenses/by/4.0/), which permits unrestricted reuse, distribution, and reproduction in any medium, provided the original work is properly cited.

ANTIQUITY 92364 (2018): 958-974

https://doi.org/10.15184/aqy.2018.71 
chronologically falls between the Mesolithic Ertebølle Culture (EBK, 5400-4000 BC) and the TRB Early Neolithic II (3500-3300 BC) (Table 1). Proposed explanations for the adoption of farming in this region include population growth, changes in resource availability, social change or some combination of these (Fischer 2002). Hypotheses about the mechanisms for such change can be grouped as migrationism, indigenism and integrationism-similar to those advanced in relation to the Neolithic Transition across Europe. Migrationism proposes the swift introduction, over just a few generations, of new technologies by incoming farmers. In contrast, indigenism argues that farming was introduced more gradually, with huntergatherers as the primary actors, obtaining new ideas and technologies from neighbouring farmers. Integrationism represents a middle ground, combining both migrationism and indigenism. Implicit in both indigenism and integrationism is that it is possible for huntergatherers to learn how to farm. The debate therefore ultimately centres on the role of local foragers.

In this paper, we critically examine the late EBK (c. 4400-4000 BC) and the early TRB, the Early Neolithic Ia and Ib (4000-3800 BC and 3800-3500 BC) of Southern Scandinavia (here inclusive of northern Germany and Poland) (Table 1; Sørensen 2014: 5). We consider the relationship between the last foragers and the first farmers, focusing on evidence for continuity and change, and its chronology. We also reconsider the overall framework for understanding settlement, and specifically the relationship between settlement sites and hunting stations. In comparison with the archaeological and ethnographic record of other regions, we present the case that the transition to farming was a process ongoing in the Early Neolithic I.

Table 1. The chronology of the Neolithic Transition in Southern Scandinavia.

\begin{tabular}{lcr}
\hline Period & Abbreviation & cal BC \\
\hline & & \\
Late Ertebølle & EBK & $4400-4000$ \\
Early Neolithic Ia & EN Ia & $4000-3800$ \\
Early Neolithic Ib & EN Ib & $3800-3500$ \\
Early Neolithic II & EN II & $3500-3300$ \\
Middle Neolithic I-II & MN I-II & $3300-3000$ \\
\hline
\end{tabular}

\section{Change in the late fifth and early fourth millennia $\mathrm{BC}$}

From $c .4400$ BC, limited numbers of Neolithic artefacts appear in Southern Scandinavia. While not the start of the Neolithic, this sparse evidence may indicate the beginning of a process of expanding contact between foragers and farmers. At the site of Flintbek in Schleswig-Holstein, for example, a pit filled with short-necked funnel beakers, flake cores and scrapers has been ${ }^{14} \mathrm{C}$ dated to between 4300 and $3900 \mathrm{BC}$ (Zich 1993). It is thus one of the earliest discoveries of funnel beaker ceramics in northern Germany. 


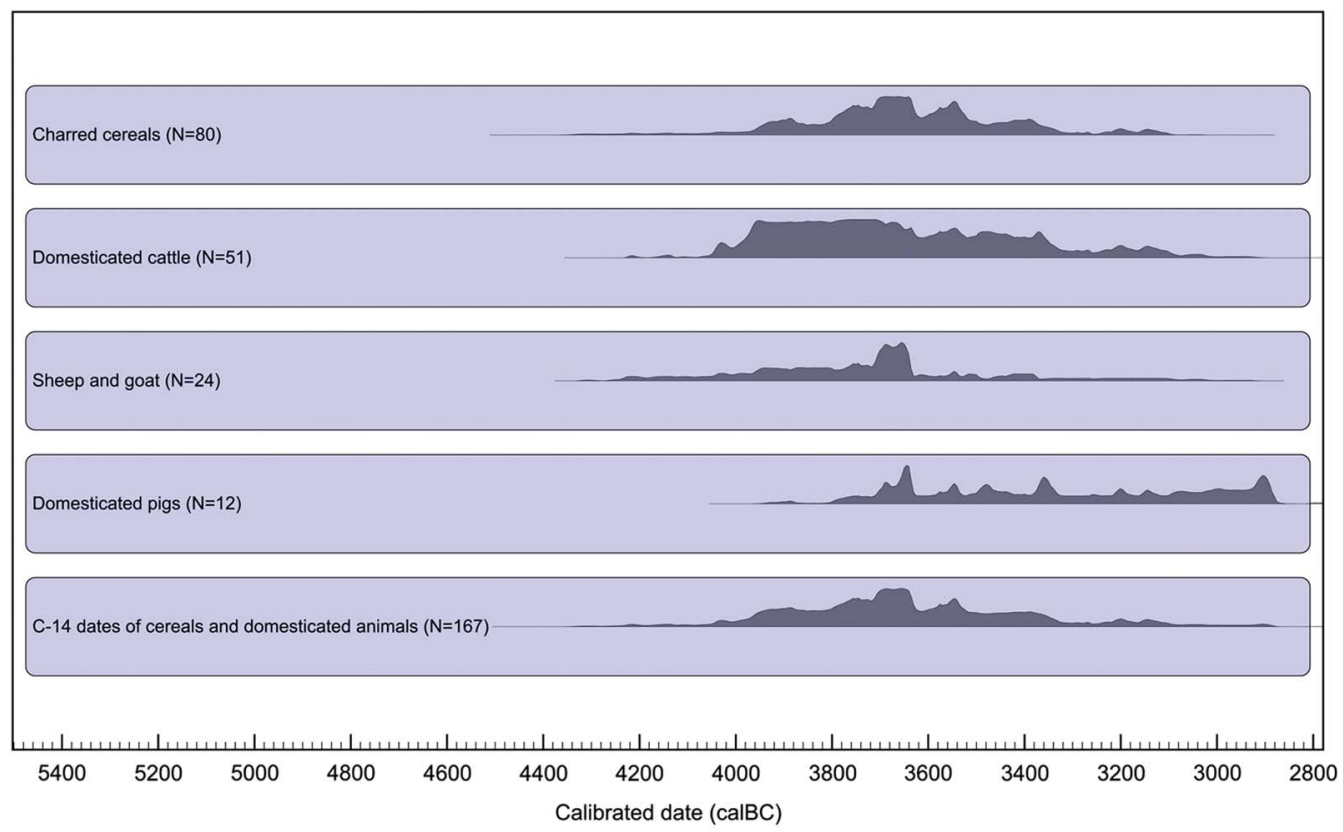

Figure 1. Available ${ }^{14} \mathrm{C}$ dates for the arrival of domesticates to Southern Scandinavia (see Karlsen et al. 2013; Sorensen 2014; Andersson et al. 2016; Gron et al. 2016; Nielsen \& Nielsen in press and references therein. See Table S1 in the online supplementary material for the individual dates). Calibration using OxCal v4.3.2 (Bronk Ramsey 2009).

Evidence for farming becomes widespread from c. $4000 \mathrm{BC}$, documented through compiled ${ }^{14} \mathrm{C}$ dates of charred cereals and domesticated animals (see Sørensen 2014; Figure 1). Late EBK pottery, adzes and T-shaped antler axes disappear, and TRB material culture, including short-necked funnel beakers, clay discs and spoons, pointed-butted flint axes and battle-axes, appears. Major changes in lithic production include a general shift from blade tools to flake tools, and the replacement of adzes with polished pointed-butted axes (Stafford 1999; Sørensen 2012). Other developments include two-aisled houses and flint mines (Sørensen 2014).

A change in symbolic behaviour is also apparent. The deliberate deposition of material culture is almost non-existent during the EBK (although see Karsten 1994; Koch 1998; Berggren 2007), so deposits of many pointed-butted axes and short-necked funnel beakers during the TRB document a significant change (Klassen 2004; Rudebeck 2010; Sørensen 2014). Some 200 years later, deliberate cattle sacrifice appears, wherein animals were dispatched with one or several blows to the forehead (Price \& Noe-Nygaard 2009). Such intentional deposits could be seen to demonstrate continuity between the last EBK and the earliest TRB at places such as Hindbygården (Berggren 2007), but, generally, evidence for EBK deposition is limited.

The most profound change appears to concern human diet (Fischer et al. 2007), with a near-complete shift from marine to terrestrial foods. In Denmark, however, there are currently only two humans securely dated to the Early Neolithic from coastal sites, one each from Sejerø and Dragsholm, the former demonstrating a marine diet and the latter terrestrial (C) Antiquity Publications Ltd, 2018. 


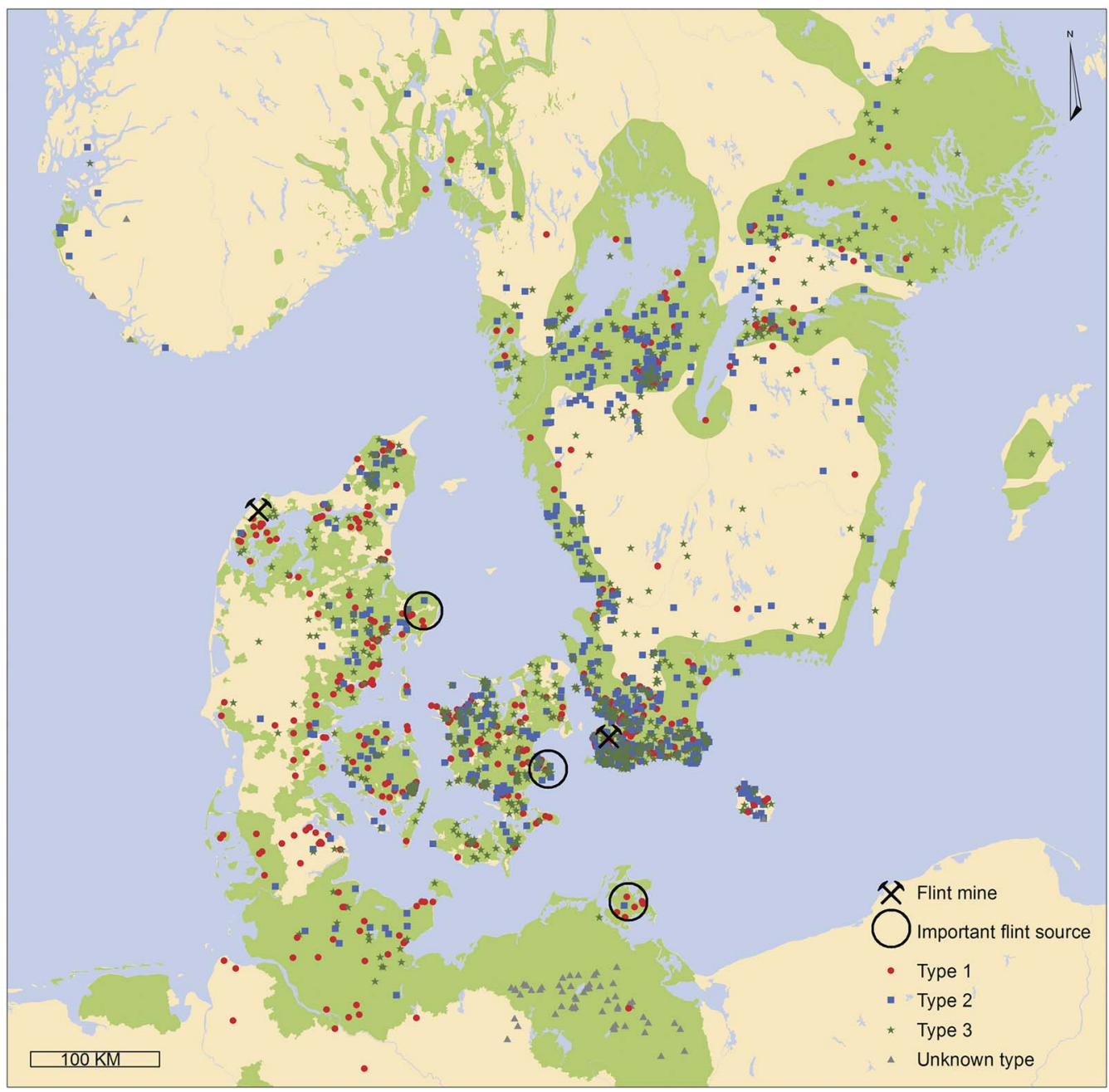

Figure 2. The distribution of pointed-butted flint axes from the Early Neolithic overlaying current and historic arable land (green) (after Odgaard 1999; Krings 2010; Sørensen 2014).

(Fischer et al. 2007). Several other humans also indicate strongly terrestrial or marine diets, although they could be either Late Mesolithic or Early Neolithic, depending on the marine reservoir correction and the $2 \sigma$ ranges (Fischer et al. 2007). While such a sharp dietary shift is not universally accepted at the outset of the Neolithic (see Milner et al. 2006), the evidence does support a dietary shift at some point during the Early Neolithic I, and the isotope values show that diet was predominantly terrestrial from c. 3800 BC. Linked to this shift in diet, there is also strong evidence for change in settlement organisation, with a new type of inland site located on easily worked arable soils. A recent survey of the distribution of pointedbutted axes, dated to 4000-3700 BC, illustrates that the earliest farmers preferred these soils which are mostly found in areas with formerly limited EBK habitation (Sørensen 2014) (Figure 2). Echoing the location of sites in areas of workable soils, plough marks provide

(C) Antiquity Publications Ltd, 2018. 
direct evidence of Early Neolithic I cultivation. Some examples have been found beneath later long barrows, indicating that ploughs were in use from the beginning of the Neolithic (Beck 2013).

Archaeobotanical data offer further insights. Pollen analyses from Scania, the southernmost region of Sweden, show concentrations of charcoal dust dating to $c .4000$ BC, possibly indicating slash-and-burn cultivation (Digerfeldt \& Welinder 1989). Other pollen diagrams from $c .4000 \mathrm{BC}$ show higher concentrations of ribwort plantain (Plantago lanceolate) and birch (Betula sp.), which may indicate a fallowing strategy (Sørensen 2014). Elevated $\delta^{15} \mathrm{~N}$ values of charred cereal grains from Stensborg in Sweden dating to the later Early Neolithic Ib confirm the selective application of animal manure, indicating an integrated agrarian package (Gron et al. 2017). As for livestock, carbon and oxygen isotope analyses of sequentially sampled cattle tooth enamel indicate that animals were born throughout the year (Gron et al. 2015). The dietary isotope analyses of a variety of wild and domestic herbivores further show that cattle were not living or being fed in forests (Gron \& Rowley-Conwy 2017), but were instead living in open anthropogenic environments. Lastly, strontium isotope analyses suggest the movement of cattle over considerable distances by boat (Gron et al. 2016), indicating a community of interconnected farms.

In sum, the earliest farming of Southern Scandinavia was a sophisticated undertaking featuring manuring and crop production, but without widespread forest clearance (Regnell $\&$ Sjögren 2006). The data therefore speak to an integrated, landscape-wide system of smallscale farming from its outset-a clean break from a Mesolithic way of life.

\section{Continuity in the late fifth and early fourth millennia BC}

As well as change, there is also remarkable evidence of continuity between the Late Mesolithic and Early Neolithic. The lithic toolkit found at the earliest TRB sites is almost indistinguishable from its EBK counterpart, and the production of blades and flake axes continues into the Early Neolithic (Nielsen 1985; Andersen 1991; Fischer 2002). Furthermore, the earliest characteristically Neolithic polished flint pointed-butted axes may have developed from EBK core axes, and some axe types and manufacturing techniques more characteristic of the EBK persist into the TRB (Jennbert 1984; Ravn 2011). Similarly, some of the earliest TRB ceramics show similarities with Mesolithic vessels and are hard to differentiate (Andersen 2011). Charred food crusts from ceramics also show continuity, demonstrating a continuation of the cooking of marine foods (Craig et al. 2011).

Continuity of settlement between the Late Mesolithic and Early Neolithic is documented by persistent occupation at a number of EBK kitchen middens, with Early Neolithic I activity directly overlying Mesolithic layers (Andersen 2004). At several of these sites, the faunal material has been successfully assigned to either the Mesolithic or Neolithic phasesmost notably at Visborg, Bjørnsholm and Sølager (Skaarup 1973; Bratlund 1993; Enghoff 2011) (Figure 3). At all of these sites, and in both the EBK and TRB, wild species dominate. The overall impression is of largely unchanged local subsistence strategies (Figure 3), except for the low-level inclusion of domestic species in the Neolithic layers (see below).

Studies from the kitchen middens also show that most of the layers dated to 4000-3700 $\mathrm{BC}$ contain limited evidence associated with farming in the form of charred grains, clay discs (C) Antiquity Publications Ltd, 2018. 


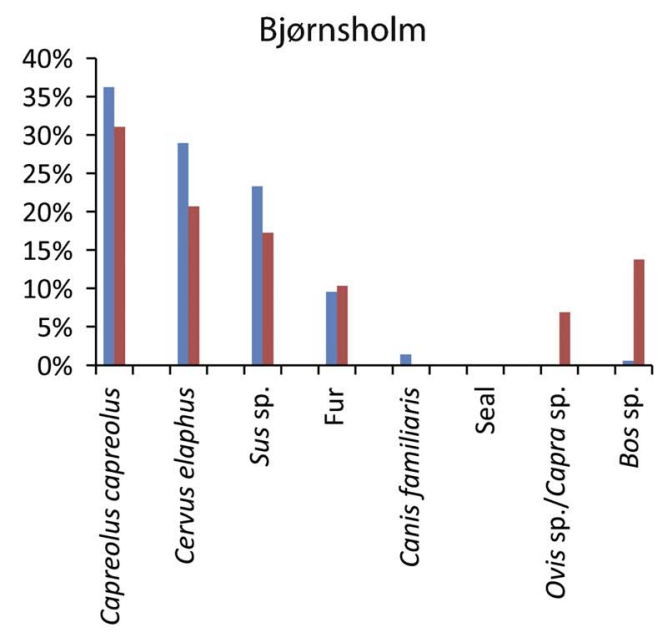

\begin{tabular}{|cc|}
\hline $\begin{array}{c}\text { Bjørnsholm } \\
\text { Mesolithic } \mathrm{N}=356 \\
\text { Neolithic } \mathrm{N}=29\end{array}$ & Mesolithic \\
$\begin{array}{c}\text { Veolithic } \\
\text { Visborg } \\
\text { Mesolithic } \mathrm{N}=636 \\
\text { Neolithic } \mathrm{N}=239\end{array}$ & $\begin{array}{c}\text { Sølager } \\
\text { Mesolithic } \mathrm{N}=443 \\
\text { Neolithic } \mathrm{N}=202\end{array}$ \\
\hline
\end{tabular}
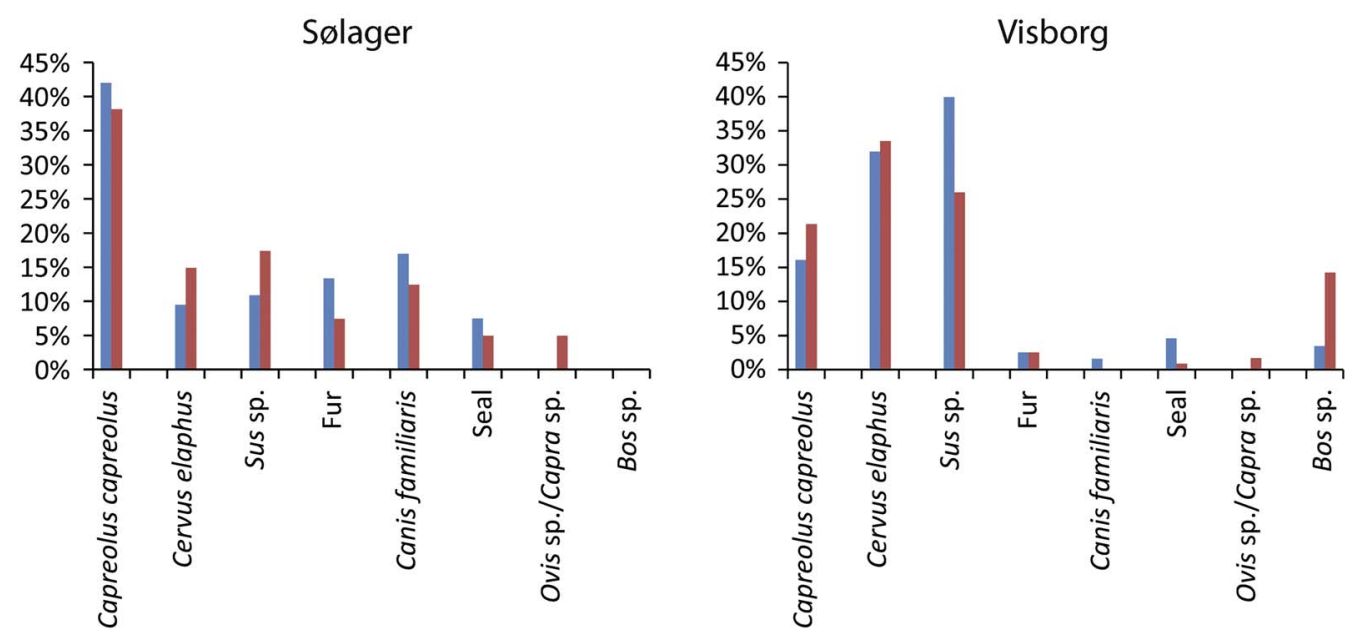

Figure 3. Mesolithic vs Neolithic fauna at Bjornsholm, Solager and Visborg (Skaarup 1973; Bratlund 1993; Enghoff 2011). Sample sizes indicate number of identified specimens. Table omits birds, amphibians, rodents and fish, as well as tentative or mixed identifications save for Sus sp. and Bos sp., where wild and domestic forms are grouped. Seal species and caprines (Ovis sp./Capra sp.) are grouped. Fur animals include Martes martes, Lynx lynx, Meles meles, Mustela putorius, Castor fiber, Lutra lutra, Felis silvestris, Vulpes vulpes and Canis lupus.

(baking plates) and grinding stones (Sørensen 2014). Only later Early Neolithic kitchen middens layers dated to 3600-3300 BC have yielded these artefacts. The midden evidence for continuity from the Mesolithic to Neolithic is unassailable.

\section{Settlement and hunting stations}

The conflicting evidence of continuity and change has resulted in an uneasy compromise within existing explanatory models. Since the 1970s, two types of Early Neolithic I sites have been recognised: settlements and hunting stations (or 'catching sites') (Skaarup 1973; Johansen 2006). Among several differences between these types, including location, topography and size, a primary distinction concerns the composition of the faunal

(C) Antiquity Publications Ltd, 2018. 
assemblages. Despite difficulties differentiating some wild from domestic species, hunting stations are dominated by wild animals and settlement sites by domestic ones (RowleyConwy 1995; Table S2). Due to their shared TRB material culture, however, it has always been assumed that the same group of people occupied the two site-types with the ubiquitous - but low-percentage-presence of domesticates attributed to provisions brought to hunting stations (Skaarup 1973; Johansen 2006). Yet is this probable? The ethnohistory of European-indigenous contact offers some perspective. In the seventeenth-century Massachusetts colonies of North America, livestock were often caught in Native American traps intended for deer, and local indigenous inhabitants killed or stole cattle for subsistence, retribution or by accident (Anderson 1994). Furthermore, domestic species including cattle, pigs and horses commonly escaped and became feral at this time (Gray 1933). This was so common that in Florida, the hunting of feral livestock became a reliable source of food; elsewhere, such hunting had to be regulated by colonial officials (Gray 1933). By extension, it is possible that domesticates at Early Neolithic I hunting stations were animals that were hunted, trapped or stolen - something that possibly occurred in the EBK (Zeder \& RowleyConwy 2014). Similarly, the low proportion of wild species at the settlement sites is consistent with those of immigrant frontier farmers elsewhere in Neolithic Europe and in the ethnohistoric record. LBK faunal assemblages usually comprise less than 10 per cent wild animals and, more broadly, less than 25 per cent in Early Neolithic Europe (see Bickle \& Whittle 2013; Manning et al. 2013). Eighteenth-century South Carolina frontier farms show a similar pattern. These settlements were located away from colonial townships in the backcountry, with economies based primarily on cattle husbandry (Groover \& Brooks 2003). At sites of this type, domestic fauna dominate assemblages, with wild game contributing approximately $20-30$ per cent.

If faunal assemblages are different, however, the presence of similar material culture at these two site types requires explanation. It is clear that distinct groups can share a material culture. For example, around the time of European contact in the eastern USA, Mohawk and Mahican ceramic traditions were shared, even though groups had different social and political affiliations and spoke different languages (Grumet 1992). Similarly, ethnographic evidence for the transfer of technology and material culture between populations, including foragers and farmers, is also common (Moorehead 1966; Yin 2006). For example, the neighbouring farmers of the last remaining hunter-gatherers of Borneo, the Penan, tried to persuade the latter to start farming (Nicolaisen 1975, 1976). Some Penan tried to grow rice but gave up, sometimes abandoning their fields near maturation in favour of pig hunting-a higher-prestige activity. That they did not return to harvest the rice suggests that they were less interested in food production than in closer social relations with the farmers through marriage alliances and new material culture (Nicolaisen 1975, 1976). Native Americans in the Southeastern USA did not adopt domestic animals until several centuries of contact with Europeans had passed (Pavao-Zuckerman \& Reitz 2006). Elsewhere, the process took only decades. The seventeenth-century New England Wampanoag, for example, adopted pigs after 30 years-encouraged by deforestation, which reduced the availability of game (Anderson 1994). This illustrates a wider trend in seventeenth-century New England, in which Native Americans selectively adopted pigs over other domesticated species, usually after decades of contact (Anderson 1994).

(C) Antiquity Publications Ltd, 2018. 


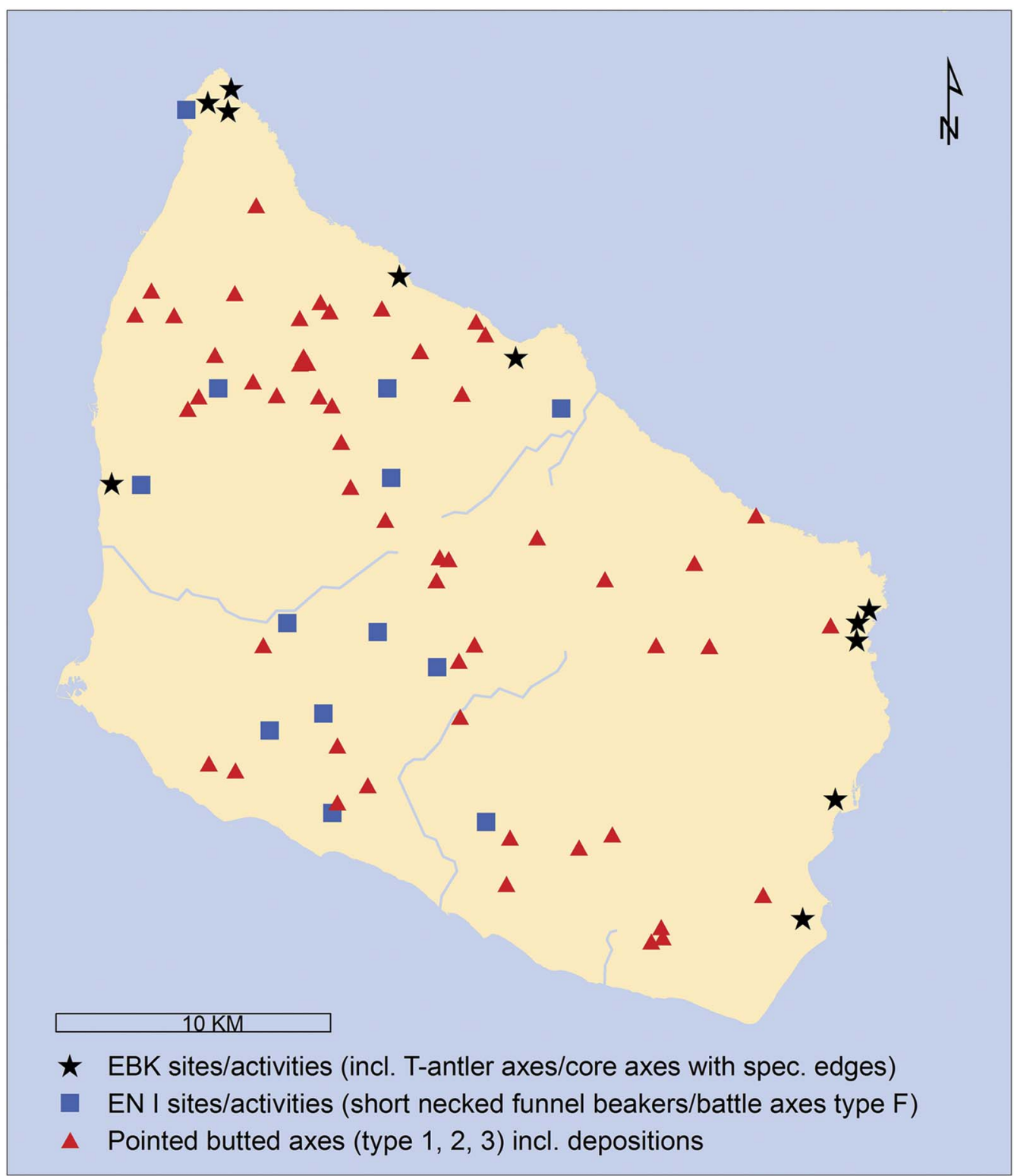

Figure 4. The shift from coastal to inland settlement on Bornholm, Denmark (see Sørensen 2014 and references therein).

Returning to the Neolithic Transition in Southern Scandinavia, these parallels suggest no reason to assume that the adoption of domestic animals by indigenous groups would have happened quickly. Further, it is equally possible to assume that foragers occupied hunting stations and farmers the settlement sites, as it is to assume that commuting farmers occupied both. In practice, each of these scenarios could have occurred simultaneously in different areas, depending on the social engagement between the hunter-gatherers and farmers. It is perfectly plausible that some regions had two population groups, while others had one 


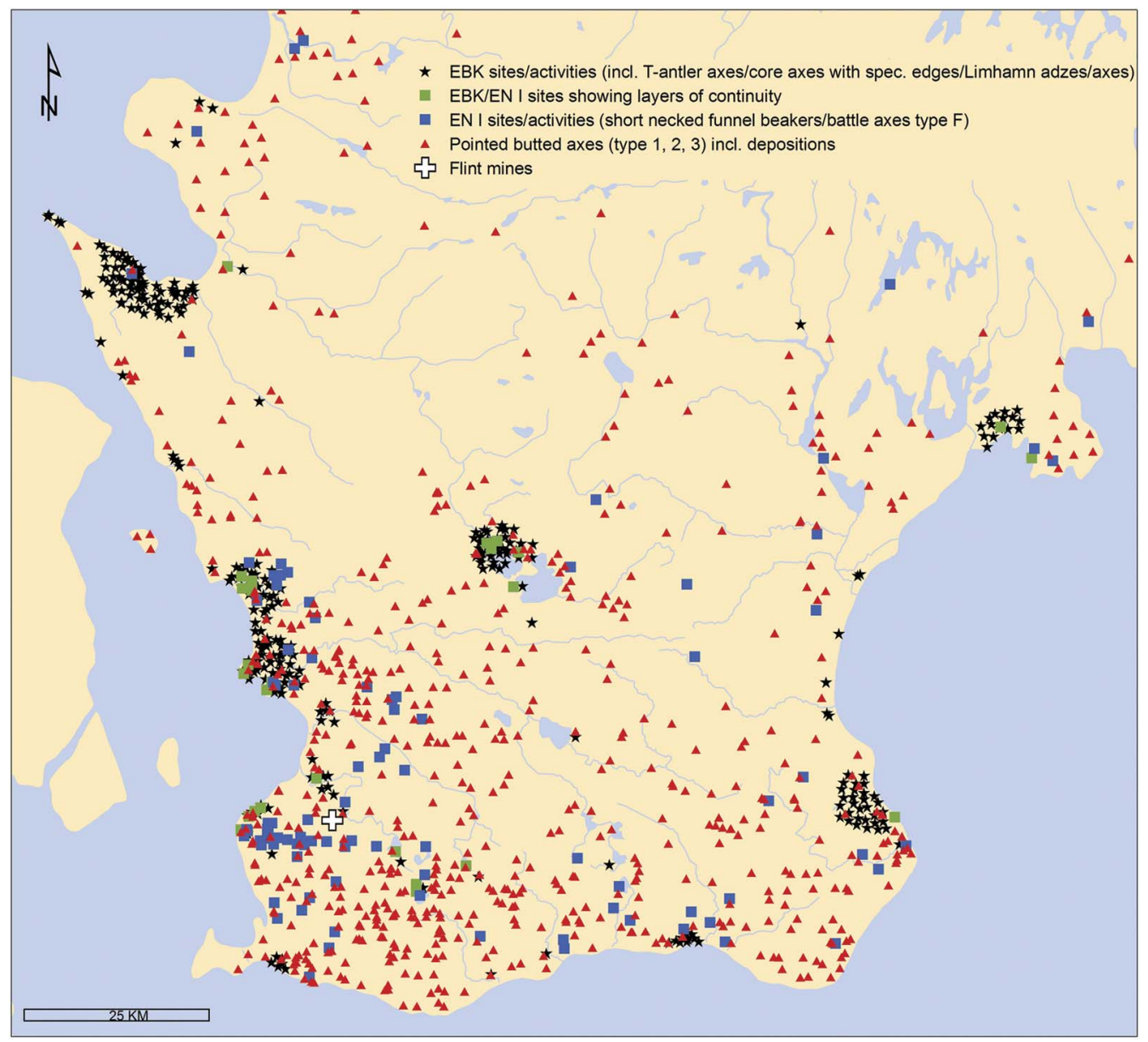

Figure 5. The shift from coastal to inland settlement in Scania, Sweden (see Sørensen 2014 and references therein).

moving between inland and coastal areas. This plurality is, in fact, precisely what is observed in the archaeological record. The reason may lie in biogeography. Long, relatively straight exposed coasts are much less productive than heterogeneous coastal environments with a large spectrum of ecosystems (e.g. estuaries, peninsulas, straits, islands and the like) (see Paludan-Müller 1978). Indeed, it seems that the transition was abrupt on Bornholm (Figure 4) and in Scania (Figure 5), places with long, exposed coasts, and with a quick replacement of foraging with farming corresponding to a shift from coastal to inland settlement (Nielsen 2009). In contrast, in northern Jutland, with its many islands, inlets and estuaries, both coastal and inland settlements occur in the Early Neolithic (Figure 6).

\section{A chronological model}

If foragers and farmers subsisted side by side, what does this mean for the Neolithic Transition? It is not only the presence or absence of continuity that matters, but its timing and duration. Both change and continuity in subsistence and material culture from the EBK (C) Antiquity Publications Ltd, 2018. 


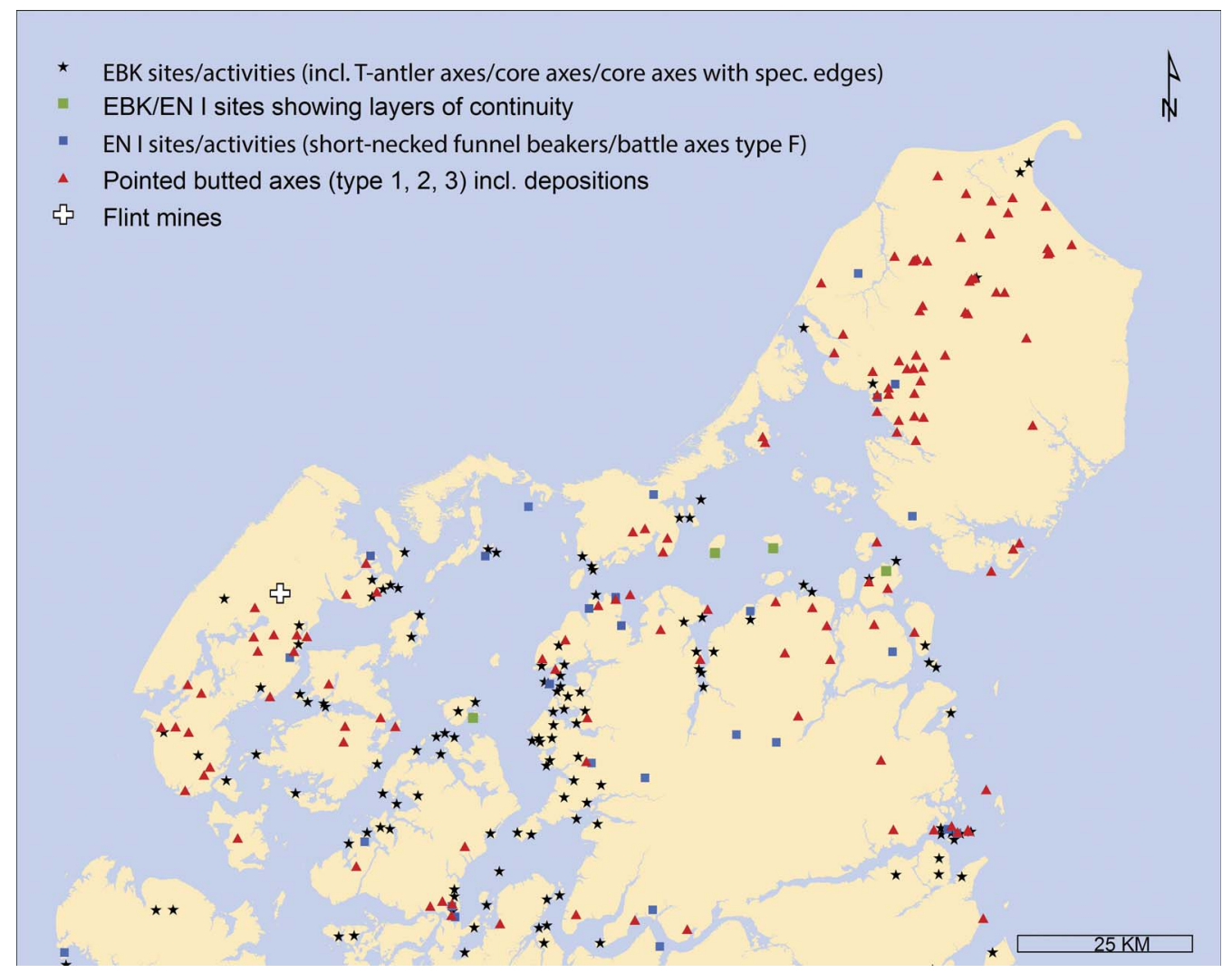

Figure 6. Mesolithic and Neolithic coastal settlement in north Jutland, Denmark (see Sørensen 2014 and references therein).

through the Early Neolithic I can be traced chronologically. Figure 7 shows a clear relationship between the gradual introductions of new practices concurrent with the gradual disappearance of old ones. As such, there is no reason to expect an abrupt demographic and economic replacement $c .4000 \mathrm{BC}$. We propose that the earliest centuries of the Funnel Beaker Culture were a period of cultural and economic mixing and negotiation between the last foragers and the first farmers. This scenario accounts both for the idiosyncrasies within the early data and for the subsequent emergence of a coherent TRB starting in the Early Neolithic II. It implies that an entirely new understanding of the culture-history of Scandinavia in the earliest years of the Neolithic is needed. Questions that consequently arise include: how long did this situation persist? How much contact occurred and how often? Should we expect genetic exchange between farmers and foragers?

Any widespread cultural or economic duality could not have persisted longer than the Early Neolithic I. After the introduction of domesticates there is a gradual reduction in hunting and foraging activities, and the appearance of new cultural practices. These include cattle sacrifice, the construction of long barrows and new forms of material culture, as well as the increasing frequency of artefacts associated with cereal agriculture. As most of these 


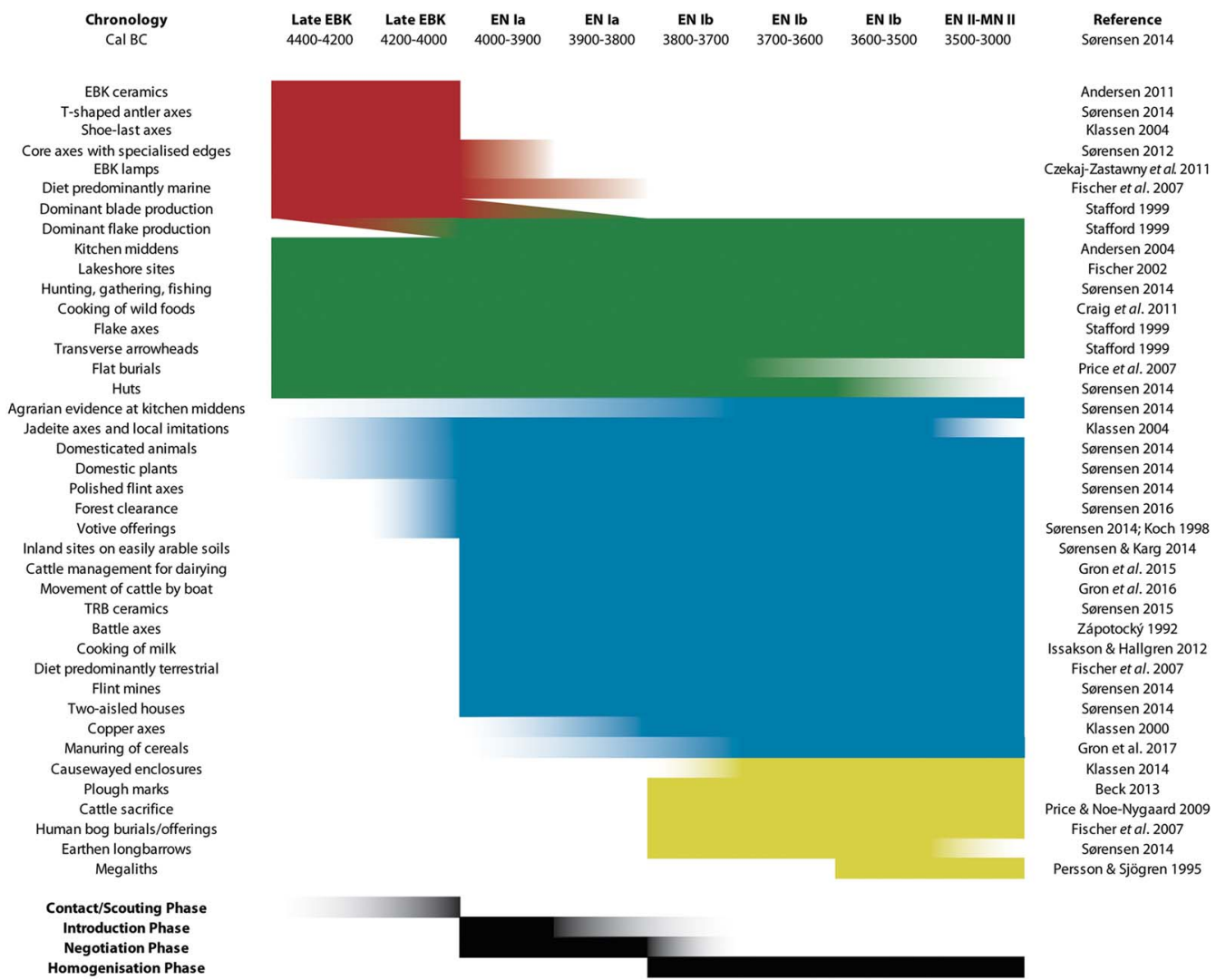

Figure 7. The chronological development of the Early Neolithe I (red = disappearance; green = continuity; blue = change; and yellow $=$ subsequent developments). Dominant blade and flake production are connected as the toolkit is similar.

developments are in evidence by $c .3700 \mathrm{BC}$, we suggest that any duality had largely disappeared by this time. Four phases can be identified (Figure 7):

1) Contact/Scouting phase (from $c .4400 \mathrm{BC}$ )

2) Introduction phase (from $c .4000 \mathrm{BC}$ )

3) Negotiation phase (c. 4000-3700 BC)

4) Homogenisation phase (after $c .3700 \mathrm{BC}$ )

The Contact/Scouting phase starts c. $4400 \mathrm{BC}$, during which the first signs of the Neolithic emerge. Although this is not the Neolithic proper, it represents the initiation of contacts that will later facilitate the movement of incoming farmers. From this period, rare finds of Neolithic origin occur, including impressions of cultivated grains in EBK ceramics and the earliest examples of TRB pottery and polished axes as isolated finds. These suggest direct contact between Neolithic farmers and EBK hunter-gatherers.

The Introduction phase marks the start of the Neolithic in Scandinavia and the Funnel Beaker Culture in the region. It is during this phase that initial immigrants arrived from

(C) Antiquity Publications Ltd, 2018. 
elsewhere, bringing certain forms of material culture and domesticated plants and animals. Considerable flexibility in the model is required with regard to scale and duration: this phase may have lasted as late as $c .3700 \mathrm{BC}$, or only for a few decades. Regardless, there is little evidence to suggest any persistence of Mesolithic practices beyond $c .3700 \mathrm{BC}$, and any incoming population movements may have been restricted to only a short time after $c .4000$ $\mathrm{BC}$, with subsequent developments attributable to internal processes.

The Negotiation phase also starts at the very beginning of the Neolithic, concurrent with, but perhaps persisting longer than, the Introduction phase. As with the Introduction phase, the duration of this phase cannot be known. During this period, both foraging and farming strategies were practised (see Rowley-Conwy 2004), with regional variations, and with cultural negotiation between populations. This negotiation phase almost certainly ended $c$. $3700 \mathrm{BC}$, marked by the appearance of new forms of material culture and practices, such as long barrows, causewayed enclosures, cattle sacrifice and changes in the prevalence of agricultural equipment within shell middens. Foragers and farmers appear to share material culture, but not subsistence strategies, with the farmers based at settlement sites and foragers, descended from EBK groups, at the hunting stations. Contact is certain, and genetic exchange probably occurred. Newly arrived TRB material culture hybridised quickly with EBK forms, with changes to settlement and subsistence following later. Ethnographic comparisons predict exactly this sort of progression, with material goods widely exchanged upon contact, and subsistence shifting only in the context of major societal reorganisation (Verhart 2003). This phase features the manufacture of transitional forms of material culture, with the flow of ideas moving in both directions.

The Homogenisation phase begins roughly when the dual presence of foraging and farming has shifted decisively in favour of the latter. There is a progressive decline in the exploitation of wild resources, an increase in the role of domestic species, deforestation and the appearance of new cultural practices, including the building of large-scale monuments. It is only now that the transition to a Neolithic way of life is complete. Given the evidence of continuity and discontinuity (Figure 7), we suggest that this phase probably started by c. $3700 \mathrm{BC}$ and no later than $c .3500 \mathrm{BC}$.

\section{Discussion}

The strength of our model is its ability to accommodate the contradictory evidence for continuity and change at the heart of contention over the origins of agriculture in Southern Scandinavia. It negates what are almost certainly simplistic explanations and allows for a degree of regional variation. At its core is recognition that the Neolithic Transition was a process that varied across time and space, and hence it can better accommodate and explain the geographic variability in evidence documented in the centuries after $4000 \mathrm{BC}$. Our model does not replace the three-phase model of Zvelebil and Rowley-Conwy (1984), but instead applies it repeatedly across time. The hunting stations are evidence of groups in the Substitution phase (Zvelebil \& Rowley-Conwy 1984), while the contemporaneous settlement sites represent either groups already in the Consolidation phase, or incoming farmers. To emphasise this, the percentages of wild $v s$ domestic species in the faunal 
assemblages from hunting stations contexts (Table S2) fit nicely into the ethnographic societies described by Rowley-Conwy (2004: fig. 7b) as undertaking the Substitution phase.

We argue that it may be impossible to define and match distinct material cultures to incoming farmers, the last foragers and groups intermediate to the two. Due to the strong possibility of inter-marriage and the associated transfer of skills, styles and traditions, any simple link between people and pots is meaningless. New forms of material culture and practice, however, are present from the outset, and are concurrent with the persistence of, or similarities with, earlier forms (Figure 7). From this, we surmise that during the Negotiation phase, the demographic balance between incoming farmers and the last foragers was relatively equal. Several lines of evidence support this assertion. Firstly, widespread forest clearance is rare before the Standardisation phase, which is an argument against large-scale immigration (Gron \& Rowley-Conwy 2017). Secondly, cattle were moved (Gron et al. 2016), possibly to maintain the breeding viability of very small herds at scattered frontier farms. Despite a general lack of MNI (minimum number of individuals) determinations, even the largest faunal assemblages are unlikely to represent more than a dozen or so animals-below the threshold of long-term herd viability (Bogucki 1988). Perhaps most telling is the lack of large investment in communal construction during the Negotiation phase: there are no causewayed enclosures, despite the existence of such large-scale monuments in the regions from which the immigrants probably originated (Sørensen 2014). There were not enough farmers to build them.

\section{Conclusions}

There is a need to shift the theoretical focus from top-down discussions of how agriculture came to Scandinavia to instead on how farming practices were actually transferred between societies. How did agriculture come to this region and why did it take time? The example of Southern Scandinavia demonstrates that the Neolithic Transition was dictated by a combination of factors, including demography, biogeography, subsistence and cultural practices. While each individual European Neolithic Transition occurred within its own unique setting, our model is probably applicable whenever indigenous foragers-in the face of incoming migrants-were able to maintain their traditional subsistence strategy for any length of time. As such, we suggest that the data indicate a period of economic and probable cultural negotiation, during which agriculture came to Scandinavia. Recent research has allowed a more nuanced understanding of agricultural origins by investigating, at a much finer scale, the timing and complexity of economic and cultural change during the earliest years of the Neolithic. Our approach does not require us to choose between migrationism, indigenism or integrationism, but instead looks to a combination of these, played out over time, indicating a process of economic, and probable cultural, dualism in the earliest centuries of the Funnel Beaker Culture. Our model is imperfect, but it is consistent with the existing data and flexible enough that it might incorporate new evidence in the future.

\section{Acknowledgements}

We thank three anonymous colleagues for their thoughtful comments. K.J.G. and L.S. thank the Leverhulme Trust and the Carlsberg Foundation, respectively, for funding.

(C) Antiquity Publications Ltd, 2018. 


\section{Supplementary material}

To view supplementary material for this article, please visit https://doi.org/10.15184/aqy.2018.71

\section{References}

Andersen, S.H. 1991. Norsminde: a 'køkkenmødding' with Late Mesolithic and Early Neolithic occupation. Journal of Danish Archaeology 8: 13-40.

- 2004. Danish shell middens reviewed, in A. Saville (ed.) Mesolithic Scotland and its neighbours: 393411. Edinburgh: The Society of Antiquaries of Scotland.

- 2011. Kitchen middens and the early pottery of Denmark, in S. Hartz, F. Lüth \& T. Terberger (ed.) Frühe Keramik im Ostseeraum-Datierung und Sozialer Kontext. Internationaler Workshop in Schleswig vom 20. bis 21. Oktober 2006

(Bericht der Römisch-Germanischen

Kommission Band 89): 193-216. Mainz: Phillip von Zabern.

Anderson, V.D. 1994. King Philip's herds: Indians, colonists, and the problem of livestock in early New England. The William and Mary Quarterly 51: 601-24.

https://doi.org/10.2307/2946921

Andersson, M., M. Artursson \& K. Brink. 2016. Early Neolithic landscape and society in southwest Scania—new results and perspectives. Journal of Neolithic Archaeology 18: 23-114.

BeCK, M.R. 2013. Højensvej Høj 7—en tidligneolitisk langhøj med flere faser. Aarbøger for Nordisk Oldkyndighed og Historie 2011-2012: 33-118.

Berggren, Å. 2007. Till och frän ett kärr: den arkeologiska undersökningen av Hindbygården. Malmöfynd nr 17. Malmö: Malmö Kulturmiljö.

Bickle, P. \& A. Whittle (ed.). 2013. The first farmers of Central Europe: diversity in $L B K$ lifeways. Oxford: Oxbow.

BoGUCKI, P. 1988. Forest farmers and stockherders. Cambridge: Cambridge University Press.

Bratlund, B. 1993. The bone remains of mammals and birds from the Bjørnsholm shell-mound: a preliminary report. Journal of Danish Archaeology 10: 97-104.

Bronk Ramsey, C. 2009. Bayesian analysis of radiocarbon dates. Radiocarbon 51: 337-60. https://doi.org/10.1017/S0033822200033865
Craig, O.E., V.J. Steele, A. Fischer, S. Hartz, S. H. Andersen, P. Donohoe, A. Glykou, H. Saul, D.M. Jones, E. Koch \& C.P. Heron. 2011. Ancient lipids reveal continuity in culinary practices across the transition to agriculture in Northern Europe. Proceedings of the National Academy of Sciences of the USA 108: 17910-5. https://doi.org/10.1073/pnas.1107202108

Czekaj-Zastawny, A., J. Kabaciński \& T. Terberger. 2011. Cultural relations between the Great Hungarian plain and the southern Baltic coast. Imports from the Bodrog-Keresztúr Culture on the Site Dąbki 9. Sprawozdania Archeologiczne 63: 55-88.

Digerfeldt, G. \& S. Welinder. 1989. The prehistoric cultural landscape in southwest Sweden. Acta Archaeologica 59: 127-36.

ENGHoff, I.B. 2011. Regionality and biotope exploitation in Danish Ertebolle and adjoining periods. Copenhagen: The Royal Danish Academy of Sciences and Letters.

Fischer, A. 2002. Food for feasting, in A. Fischer \& K. Kristiansen (ed.) The Neolithisation of Denmark - 150 years of debate: 343-93. Sheffield: Collis.

Fischer, A., J. Olsen, M. Richards, J. Heinemeier, Á.E. Sveinbjörnsdóttir \& P. Bennike. 2007. Coast-inland mobility and diet in the Danish Mesolithic and Neolithic: evidence from stable isotope values of humans and dogs. Journal of Archaeological Science 34: 2125-50. https://doi.org/10.1016/j.jas.2007.02.028

Gray, L.C. 1933. History of agriculture in the southern United States to 1860. Washington, D. C.: Carnegie Institution of Washington.

Gron, K.J. \& P. Rowley-Conwy. 2017. Herbivore diets and the anthropogenic environment of early farming in Southern Scandinavia. The Holocene 27: 98-109. https://doi.org/10.1177/0959683616652705

Gron, K.J., J. Montgomery \& P. RowleyConwy. 2015. Cattle management for dairying in Scandinavia's earliest Neolithic. PloS One 10: e0131267.

https://doi.org/10.1371/journal.pone.0131267

Gron, K.J., J. Montgomery, P.O. Nielsen, G.M. Nowell, J.L. Peterkin, L. Sørensen \& P.

(C) Antiquity Publications Ltd, 2018. 
Rowley-Conwy. 2016. Strontium isotope evidence of early Funnel Beaker Culture movement of cattle. Journal of Archaeological Science: Reports 6: 248-51. https://doi.org/10.1016/j.jasrep.2016.02.015

Gron, K.J., D.R. Gröcke, M. Larsson, L. Sørensen, L. Larsson, P. Rowley-Conwy \& M.J. Church. 2017. Nitrogen isotope evidence for manuring of Early Neolithic Funnel Beaker Culture cereals from Stensborg, Sweden. Journal of Archaeological Science: Reports 14: 575-79. https://doi.org/10.1016/j.jasrep.2017.06.042

Groover, M.D. \& R.D. Brooks. 2003. The Catherine Brown cowpen and Thomas Howell site: material characteristics of cattle raisers in the South Carolina backcountry. Southeastern Archaeology 22: 91-110.

Grumet, R.S. 1992. Historic contact: early relations between Indian people and colonists in Northeastern North America, 1524-1783. Philadelphia (PA): National Park Service.

Isaksson, S. \& F. Hallgren. 2012. Lipid residue analyses of EN Funnel-Beaker pottery from Skogsmossen, eastern Central Sweden, and the earliest evidence of dairying in Sweden. Journal of Archaeological Science 39: 3600-609. https://doi.org/10.1016/j.jas.2012.06.018

JennBert, K. 1984. Den produktiva gåvan. Tradition och innovation i Sydskandinavien för omkring 5300 år sedan. Acta Archaeologica Lundensia 4: 1-221.

Johansen, K.L. 2006. Settlement and land use at the Mesolithic-Neolithic transition in Southern Scandinavia. Journal of Danish Archaeology 14: 201-23.

Karlsen, K.B., A. Nylén, J. Ros, K. Anttila, H. Runeson \& A. Lihammer. 2013. Atterstafossil åker, skärvstenshög och medeltida gård. Förundersökning och särskild arkeologisk undersökning. Stiftelsen Kulturmiljövård Rapport 2010: 15.

Karsten, P. 1994. Att kasta yxan i sjön. Acta Archaeologica Lundensia (Series in $8^{\circ}(23)$ ): $1-360$.

KLassen, L. 2000. Frühes Kupfer in Norden. Untersuchungen zu Chronologie, Herkunft und Bedeutung der Kupferfunde der Nordgruppe der Trichterbecher-Kultur. Århus: Jutland Archaeological Society.

- 2004. Jade und Kupfer: Untersuchungen zum Neolithisierungsprozess im westlichen Ostseeraum unter besonderer Berücksichtigung der Kulturentwicklung Europas 5500-3500 BC. Århus: Jutland Archaeological Society.

- 2014. Along the road. Aspects of causewayed enclosures in South Scandinavia and beyond. Århus: Århus University Press.

Kосн, E. 1998. Neolithic bog pots from Zealand, Møn, Lolland and Falster. Copenhagen: Det Kongelige Nordiske Oldskriftselskab.

KrINGS, S. 2010. Statistisches Jabrbuch 2010 für die Bundesrepublik Deutschland mit Internationalen Übersichten. Wiesbaden: Statistisches Bundesamt.

Manning, K., S.S. Downey, S. Colledge, J. Conolly, B. Stopp, K. Dobney \& S. Shennan. 2013. The origins and spread of stock-keeping: the role of cultural and environmental influences on Early Neolithic animal exploitation in Europe. Antiquity 87: 1046-59. https://doi.org/10.1017/S0003598X00049851

Milner, N., O.E. Craig, G.N. Bailey \& S.H. Andersen. 2006. A response to Richards and Schulting. Antiquity 80: 456-58. https://doi.org/10.1017/S0003598X00093777

Moorehead, A. 1966. The fatal impact. London: Penguin.

Nicolaisen, J. 1975. The Negritos of Casiguran Bay. Problems of affluency, territoriality and human aggressiveness in hunting societies of Southeast Asia. Folk 1974/1975(16-17): 401-34.

- 1976. The Penan of Sarawak. Further notes on the neo-evolutionary concept of hunters. Folk 1976 : 205-36.

Nielsen, P.O. 1985. De første bønder: Nye fund fra den tidligste Tragtbægerkultur ved Sigersted. Aarboger for Nordisk Oldkyndighed og Historie 1984: 96-126.

- 2009. Den tidligneolitiske bosættelse på Bornholm, in A. Schülke (ed.) Plads og Rum i Tragtbagerkulturen. Bidrag fra Arbejdsmødet på Nationalmuseet, 22. September 2005: 9-24. Copenhagen: Det Kongelige Nordiske Oldskriftselskab.

Nielsen, P.O. \& F.O. Nielsen. In press. First farmers. The Early Neolithic settlement at Vallensgard, Bornholm. Copenhagen: Nordiske Fortidsminder.

OdgaARD, B. 1999. Landbrugslandskabet gennem 2000 år. Geologi Nyt fra GEUS 1: 4-6.

(C) Antiquity Publications Ltd, 2018. 
Paludan-Müller, K. 1978. High Atlantic food gathering in northwestern Zealand: ecological conditions and spatial representation. New Directions in Scandinavian Archaeology 1: $120-57$.

Pavao-Zuckerman, B. \& E.J. Reitz. 2006. Introduction and adoption of animals from Europe. Handbook of North American Indians 3: 485-91.

Persson, P. \& K.G. Sjögren. 1995. Radiocarbon and the chronology of Scandinavian megalithic graves. Journal of European Archaeology 3: 59-88. https://doi.org/10.1179/096576695800703694

Price, T.D. \& N. Noe-Nygaard. 2009. Early domestic cattle in Southern Scandinavia and the spread of the Neolithic in Europe, in N. Finlay, S. McCartan, N. Milner \& C. Wickham-Jones (ed.) From Bann flakes to Bushmills. Papers in honour of professor Peter Woodman: 135-63. Oxford: Oxbow.

Price, T.D., S.H. Ambrose, P. Bennike, J. Heinemeier, N. Noe-Nygaard, E. Brinch Petersen, P.V. Petersen \& M. Richards. 2007. New information on the Stone Age graves at Dragsholm, Denmark. Acta Archaeologica 78: 193-219.

https://doi.org/10.1111/j.1600-0390.2007. 00106.x

Ravn, M. 2011. The Early Neolithic Volling site of Kildevang-its chronology and intra-spatial organisation, in S. Hartz, F. Lüth \& T. Terberger (ed.) Frühe Keramik im Ostseeraum-Datierung und Sozialer Kontext. Internationaler Workshop in Schleswig vom 20. bis 21. Oktober 2006 (Bericht der Römisch-Germanischen Kommission Band 89): 135-63. Mainz: Philipp von Zabern.

Regnell, M. \& K.-G. Sjögren. 2006. Vegetational development, in K.G. Sjögren (ed.) Ecology and economy in Stone Age and Bronze Age Scania: 4079. Lund: National Heritage Board.

Rowley-Conwy, P. 1995. Wild or domestic? On the evidence for the earliest domestic cattle and pigs in South Scandinavia and Iberia. International Journal of Osteoarchaeology 5: 115-26. https://doi.org/10.1002/oa.1390050203

-2004 . How the West was lost: a reconsideration of agricultural origins in Britain, Ireland and Southern Scandinavia. Current Anthropology 45 (Supplement 4): S83-113.

https://doi.org/10.1086/422083
RuDEBECK, E. 2010. I trästodernas skuggamonumentala möten i Neolitiseringens tid, in B. Nilsson \& E. Rudebeck (ed.) Arkeologiska och förhistoriska världar: fält, erfarenheter och Stenåldersplatser i Sydvästra Skaine: 85-251. Malmö: Malmö Museer Arkeologienheten.

SkaARup, J. 1973. Hesselø-Solager: jagdstationen der Südskandinavischen Trichterbecherkultur. Copenhagen: Akademisk.

Sørensen, L. 2012. Fremmede økser som sædekorn for neolitisering-Agrarsamfundenes ekspansion mod Sydskandinavien, in F. Kaul \& L. Sørensen (ed.) Agrarsamfundenes ekspansion i nord. Symposium på Tanums Hälleristningsmuseum, Underslös, Bohuslän, d. 25.-29. Maj 2011: 8-30. Copenhagen: Nordlige Verdener.

-2014. From hunter to farmer in Northern Europe: migration and adaptation during the Neolithic and Bronze Age. Acta Archaeologica 85: 1-794.

- 2015. Endnu et indspark i neolitiseringsdebatten. Aktuel status inden for spredningen af agrarsamfundene. Arkaologisk Forum 33: 32-6.

- 2016. New theoretical discourses in the discussion of the neolithisation process in South Scandinavia during the late $5^{\text {th }}$ and early $4^{\text {th }}$ millennium $\mathrm{BC}$ - an identification of learning processes, communities of practice and migrations. Documenta Praehistorica XLIII: 1-27. https://doi.org/10.4312/dp.43.10

Sørensen, L. \& S. Karg. 2014. The expansion of agrarian societies towards the north-new evidence for agriculture during the Mesolithic/ Neolithic transition in Southern Scandinavia. Journal of Archaeological Science 51: 98-114. https://doi.org/10.1016/j.jas.2012.08.042

STAFFORD, M.D. 1999. From forager to farmer in fint: a lithic analysis of the prehistoric transition to agriculture in Southern Scandinavia. Aarhus: Aarhus Universitetsforlag.

Verhart, L. 2003. Mesolithic economic and social changes in the southern Netherlands, in L. Larsson, H. Kindgren, K. Knutsson, D. Loeffler \& A. Åkerlund A (ed.) Mesolithic on the move: papers presented at the Sixth International Conference on the Mesolithic in Europe, Stockholm 2000: 442-50. Oxford: Oxbow.

YIN, T. 2006. From hunters to farmers. Changing means of subsistence and food production among the Oroqen. British Food Journal 108: 951-57. https://doi.org/10.1108/00070700610709986 
ZÁротоски́, M. 1992. Streitäxte des mitteleuropäischen Äneolithikums. Weinheim: $\mathrm{VCH}$ Verlagsgesellschaft.

Zeder, M. \& P. Rowley-Conwy. 2014. Mesolithic domestic pigs at Rosenhof-or wild boar? A critical re-appraisal of ancient DNA and geometric morphometrics. World Archaeology 46: 813-24.

https://doi.org/10.1080/00438243.2014. 953704
Zich, B. 1993. Die Ausgrabungen chronisch gefährdeter Hügelgräber der Stein-und Bronzezeit in Flintbek, Kreis Rendsburg-Eckernförde. Ein Vorbericht. Offa 1992/1993 (49/50): 15-31.

Zvelebil, M. \& P. Rowley-Conwy. 1984. Transition to farming in Northern Europe: a hunter-gatherer perspective. Norwegian Archaeological Review 17: 104-28. https://doi.org/10.1080/00293652.1984. 9965402

Received: 16 June 2017; Revised: 11 October 2017; Accepted: 8 November 2017

(C) Antiquity Publications Ltd, 2018. 